\title{
PERANAN SEKTOR PERTANIAN DALAM PEMBANGUNAN WILAYAH KABUPATEN SIMALUNGUN PROVINSI SUMATERA UTARA
}

\author{
Elvin Desi Martauli ${ }^{1{ }^{*}}$ \\ 1)*Program Studi Agribisnis, Universitas Quality Berastagi \\ email : $\underline{\text { elvindesi@ymail.com }}^{1{ }^{*}}$
}

\begin{abstract}
ABSTRAK
Tujuan penelitian ini adalah untuk menganalisis peranan sektor pertanian dalam pembangunan wilayah di Kabupaten Simalungun Provinsi Sumatera Utara. Data pada penelitian ini diperoleh dari Badan Pusat Statistik Kabupaten Simalungun dan Badan Pusat Statistik Provinsi Sumatera Utara dari tahun 20152019. Hasil penelitian menunjukkan berdasarkan Nilai Produk Domestik Regional Bruto (PDRB) dapat dilihat dari pertumbuhan ekonomi pada wilayah tersebut. Jika dilihat dari PDRB Kabupaten Simalungun pada sektor pertanian, kehutanan dan perikanan memiliki potensi untuk dikembangkan. Kontribusi PDRB sektor perikanan sebesar 48,67 persen dengan laju pertumbuhan sebesar 7,32. Berdasarkan hasil analisis LQ pada sektor pertanian di Kabupaten Simalungun merupakan sektor basis atau unggul dengan sumbangan sebesar 3,44 diikuti oleh Pengadaan Air, Pengelolaan Sampah, Limbah dan Daur Ulang sebesar 1,12 dan Perdagangan Besar dan Eceran, dan Reparasi Mobil dan Sepeda Motor sebesar 1,09. Adapun komoditas sektor pertanian holtikultura tanaman dan sayuran yang memberikan kontribusi yaitu kubis dengan luas panen mencapai 2.406 hektar (21,50\%). Dari tanaman pangan yaitu padi sawah dan Kelapa sawit merupakan komoditas perkebunan dengan produksi tertinggi mencapai 555.551 ton $(97,76 \%)$.
\end{abstract}

Kata Kunci : Sektor Pertanian, Pembangunan Wilayah, Kabupaten Simalungun

\section{PENDAHULUAN}

Tujuan pembangunan nasional Indonesia untuk mewujudkan hidup masyarakat keadilan dan kemakmuran. Sehingga memerlukan perencanaan dalam pembangunan wilayah. Pembangunan merupakan proses untuk menciptakan masyarakat yang sejahtera dengan melakukan perencanaan dengan matang. Pembangunan daerah disesuaikan dengan keadaan atau potensi dari masyarakat sehingga dapat bertumbuh dan berkembang dengan memanfaatkan potensi sumber daya yang tersedia dan dapat optimal dilakukan (Juhanis, 2012).

Undang-Undang RI No.32 Tahun 2004 berisi tentang Keputusan Pemerintah Perimbangan Keuangan Antara Pusat Dan
Daerah yang kemudian mengalami perubahan menjadi Undang-Undang No 12 Tahun 2008, sehingga setiap daerah dituntut untuk dapat mampu mengembangkan daerah berdasarkan pada otonomi daerah dalam pengelolaan keuangan. (Sulistiawan, Ispriyarso dan Ristyawati, 2019), hakitat otonomi daerah dalam pengaturan keuangan meliputi kewenangan yang luas dan utuh yang berisi tentang perencanaan, pelaksanaan, pengawasan, pengendalian dan evaluasi pada berbagai aspek pemerintahan, sehingga dapat dipertanggungjawab terhadap masyarakat dan pemerintah.

Pembangunan pada dasarnya untuk melakukan suatu perubahan dari perencanaan untuk mencapai tujuan yang diinginkan. Keberhasilan dari tujuan dalam 
pembangunan nasional adalah kemampuan dari pembangunan untuk dapat menghasilkan peningkatan pertumbuhan ekonomi, pemeliharaan sumberdaya dan investasi yang dimiliki secara efisiensi (Putra, Purwanto dan Kismartini, 2013). Pembangunan pertanian berkelanjutan (Sustainable agriculture) melalui implementasi pembangunan secara berkelanjutan melalui peningkatan pendapatan dan kesejahteraan masyarakat pertanian dengan luas, dilakukan dengan peningkatan produksi hasil pertanian dengan menjaga kestabilan sumber daya lingkungan (Fadlina, Supriyon dan Soeaidy, 2013).
Sektor pertanian adalah salah satu sumber kehidupan bagi sebagian dari penduduk di Indonesia. Sektor pertanian memberikan kontribusi terhadap perekonomian daerah. (Oktavia, Hanani and Suhartini, 2016) bahwa perkembangan sektor pertanian difokuskan pada komoditas unggulan daerah, sehingga potensi yang dimiliki oleh daerah tersebut dapat dimanfaatkan dengan baik. Kontribusi sektor pertanian untuk Produk Domestik Bruto (PDB) Indonesia dapat dilihat pada tabel 1.

Tabel 1. Kontribusi Sektor Pertanian Terhadap PDB Tahun 2015-2019 (Miliar Rp)

\begin{tabular}{|c|c|c|c|c|c|}
\hline \multirow[b]{2}{*}{ LAPANGAN USAHA } & \multicolumn{5}{|c|}{ TAHUN } \\
\hline & 2015 & 2016 & 2017 & 2018 & 2019 \\
\hline Pertanian, Kehutanan, dan Perikanan & $1,555,207$ & $1,671,598$ & $1,787,963$ & $1,900,804$ & $2,013,627$ \\
\hline Pertambangan dan Penggalian & 881,694 & 890,868 & $1,029,555$ & 304,999 & $1,149,914$ \\
\hline Industri Pengolahan & $2,418,892$ & $2,545,204$ & $2,739,712$ & 753,004 & $3,119,617$ \\
\hline Pengadaan Listrik dan Gas & 129,834 & 142,344 & 162,340 & 176,640 & 185,115 \\
\hline Pengadaan Air & 8,546 & 8,909 & 9,439 & 10,024 & 10,736 \\
\hline Konstruksi & $1,177,084$ & $1,287,601$ & $1,410,514$ & $1,562,297$ & $1,701,741$ \\
\hline $\begin{array}{l}\text { Perdagangan Besar dan Eceran, dan Reparasi } \\
\text { Mobil dan Sepeda Motor }\end{array}$ & $1,532,877$ & $1,635,410$ & $1,768,865$ & $1,931,819$ & $2,060,773$ \\
\hline Transportasi dan Pergudangan & 578,464 & 644,994 & 735,230 & 797,847 & 881,663 \\
\hline Penyediaan Akomodasi dan Makan Minum & 341,556 & 363,056 & 387,013 & 412,710 & 440,268 \\
\hline Informasi dan Komunikasi & 406,017 & 449,189 & 513,716 & 558,938 & 626,425 \\
\hline Jasa Keuangan & 464,400 & 520,207 & 571,204 & 616,315 & 671,356 \\
\hline Real Estate & 327,601 & 350,488 & 382,259 & 406,014 & 439,367 \\
\hline Jasa Perusahaan & 190,268 & 211,624 & 238,217 & 267,094 & 304,286 \\
\hline $\begin{array}{l}\text { Administrasi Pemerintahan, Pertahanan dan } \\
\text { Jaminan Sosial Wajib }\end{array}$ & 449,382 & 476,491 & 499,344 & 542,029 & 572,457 \\
\hline Jasa Pendidikan & 387,611 & 417,345 & 447,138 & 481,724 & 522,746 \\
\hline Jasa Kesehatan dan Kegiatan Sosial & 123,192 & 132,101 & 144,831 & 158,064 & 174,802 \\
\hline Jasa lainnya & 190,581 & 211,428 & 239,259 & 268,626 & 308,840 \\
\hline Jumlah & $11,163,206$ & $11,958,857$ & $13,066,599$ & $11,148,948$ & $15,183,733$ \\
\hline
\end{tabular}

Sumber : BPS Sumatera Utara, 2021

Tabel 1 pada sektor pertanian, kehutanan dan perikanan salah satu sektor yang memberikan kontribusi terhadap PDB di Indonesia yang mengalami peningkatan dari tahun 2015-2019. Peranan sektor pertanian dalam pembangunan nasional tidak perlu diragukan lagi. Hal ini disebabkan, sektor pertanian tidak dapat dipisahkan dalam kehidupan manusia. Ini dapat dilihat dari kebutuhan hidup akan pangan yang selalu meningkat dengan bertambahnya angka pertumbuhan manusia. 
(Syam dan Dermoredjo, 2001), ketika sektor-sektor lain mengalami goncangan, sektor pertanian tetap mampu untuk bertahan dan bertumbuh positif. Faktanya, pada saat sektor lain melakukan PHK terhadap tenaga kerja, justru sektor pertanian mampu menyerap tenaga kerja secara signifikan.

Pembangunan pertanian di Indonesia difokuskan pada peningkatan produksi pertanian sehingga mampu dalam pemenuhan kebutuhan pangan dan juga industri dalam negeri dalam bidang pertanian. Selain itu juga, potensi pertanian dalam ekspor dan peningkatan pendapatan petani dengan memberikan kesempatan untuk memperluas potensi pertanian dan untuk pemerataan pertanian pada berbagai daerah. Akan tetapi, sektor pertanian bagi sebagian daerah belum mampu memberikan kontribusi terhadap Produk Domestik Regional Bruto (PDRB) terutama bagi daerah penghasil pertanian (Hayati, Elfiana dan Martina, 2017).

Provinsi Sumatera Utara adalah salah satu provinsi di Indonesia yang memiliki potensi dalam sektor pertanian. Jika dilihat dari Produk Domestik Regional Bruto (PDRB) sektor pertanian, kehutanan dan perikanan mampu memberikan peran yang cukup baik. Jika dilihat data yang diperoleh dari BPS Sumatera Utara dari tahun 20152019 terus mengalami peningkatan positif, dimana dapat dilihat pada tahun 2015 sebesar 110.066 (miliar Rp), pada tahun 2016 sebesar 115.179 .69 (miliar Rp), pada tahun 2017 sebesar 121.300.04 (miliar Rp), pada tahun 2018 sebesar 127.202.65 (miliar Rp) dan pada tahun 2019 sebesar 133.726,02.

Kabupaten Simalungun yang merupakan bagian dari Provinsi Sumatera Utara pada sektor pertanian adalah utama pembangunan ekonomi daerah. Sektor pertanian menjadi perhatian bagi pemerintah daerah di Kabupaten Simalungun, hal ini dikarenakan potensi sektor pertanian yang sangat baik untuk dikembangkan di wilayah tersebut. Kondisi wilayah dan juga sumber daya manusia dalam bidang pertanian yang cukup baik. Sehingga penelitian ini difokuskan untuk mengetahui peranan sektor pertanian dalam pembangunan wilayah di Kabupaten Simalungun Provinsi Sumatera Utara. Untuk mengetahui peranan sektor pertanian dilakukan dengan melihat basis atau unggulan pada sektor lapangan usaha yang memberikan kontribusi terhadap pertumbuhan ekonomi yaitu dengan menggunakan data PDRB. Data yang diperoleh kemudian dianalisis dengan menggunakan Location Equation (LQ) dan Shift Share. (Bone et al., 2016) bahwa pertumbuhan ekonomi suatu daerah dapat dikatakan maju dan bertumbuh secara cepat, memiliki sektor unggulan yang mampu berdaya saing dan memiliki keunggulan kompetitif dan keunggulan komperatif.

\section{METODE PENELITIAN}

Penelitian ini dilakukan di Kabupaten Simalungun Provinsi Sumatera Utara. penelitian ini dilakukan pada bulan November dan Desember 2020. Pemilihan daerah penelitian dilakukan secara sengaja dengan pertimbangan bahwa Kabupaten Simalungun adalah salah satu kabupaten dengan sektor pertanian yang berpotensi.

Jenis data pada penelitian ini yaitu data kualitatif dan data kuantitatif. Data kualitatif adalah data yang berupa keterangan, penjelasan atau ungkapan. Data kuantitatif data yang berupa angkaangka. Data kualitatif di gunakan sebagai dasar untuk mengetahui klasifikasi, bentuk, fungsi dan makna ungkapan. Data yang dikumpulkan dalam penelitian ini adalah 
data sekunder. Data senkunder adalah data yang diperoleh melalui studi literatur dan referensi dari instansi terkait tentang peranan pertanian terhadap pembangunan wilayah Kabupaten Simalungun.

Metode yang di gunakan dalam menganalisis data pada penelitian ini adalah metode deskripif kualitatif. Fokusnya adalah penggambaran secara menyeluruh tentang bentuk, fungsi dan makna ungkapan. Metode ini menggunakan metodoelogi kualitatif dan kuantitatif sebagai prosedur penelitian yang menghasilkan data deskriptif berupa katakata tertulis atau lisan dari orangorang dan perilaku yang diamati.

Metodologi kualitatif merupakan prosedur yang menghasilkan data deskriptif berupa data tertulis atau lisan (Djaja Sudarma, 2008). Sedangkan metode kuantitatif adalah prosedur yang menghasilkan angka-angka yang berupa persentase dan data PDRB dari beberapa Dinas terkait. Lebih lanjut dijelaskan bahwa pendekatan kualitatif yang menggunakan data lisan memerlukan informan. Pada hakikatnya penelitian deskriptif kualitatif adalah suatu metode dalam meneliti status sekelompok manusia, suatu objek dengan tujuan membuat deskriptif, gambaran atau lukisan secara sistematis factual dan akurat Keputusan

- Jika LQ < 1 artinya subsektor dilihat dari produksi belum mampu untuk memenuhi kebutuhan wilayah tersebut, hal ini dapat disebabkan masih rendahnya peranan subsektor tersebut untuk mampu memenuhi kebutuhan wilayah disebabkan tidak memiliki keunggulan kompartif sehingga dimasukkan dalam kategori non basis.

- Jika LQ > 1 artinya subsektor mampu untuk berproduksi sesuai dengan kebutuhan wilayah tersebut bahkan mencapai ekspor. Oleh sebab itu, wilayah yang memiliki keunggulan komparatif didalam sektor tersebut akan disebut dengan sektor basis. mengenai fakta-fakta atau fenomena yang di selidiki.

Data yang diperoleh kemudian dilakukan analisis dengan menggunakan metode Location Quotient (LQ). Menurut (Sugiyono, 2014) Location Quotient merupakan suatu alat yang digunakan untuk mengidentifikasi komoditas unggulan suatu daerah dengan sangat sederhana baik itu kelebihan dan juga keterbatasannya. Analisis LQ ini pada umumnya digunakan untuk model ekonomi basis sehingga dapat dijadikan untuk mengukur kegiatan ekonomi dengan melakukan perbandingan. Adapun formulasi dalam Location Quetient (LQ) dirumuskan sebagai berikut :

Keterangan :

$$
L Q=\frac{S i / S}{N i /_{N}}
$$

$\mathrm{Si}=$ Jumlah produksi komoditas i di kabupaten i

$\mathrm{S}=$ Jumlah total produksi subsektor $\mathrm{i}$ di kabupaten i

$\mathrm{Ni}=$ Jumlah produksi komoditas i di dataran tinggi Provinsi Sumatera Utara

$\mathrm{N}=$ Jumlah total komoditas i di dataran tinggi Provinsi Sumatera Utara 


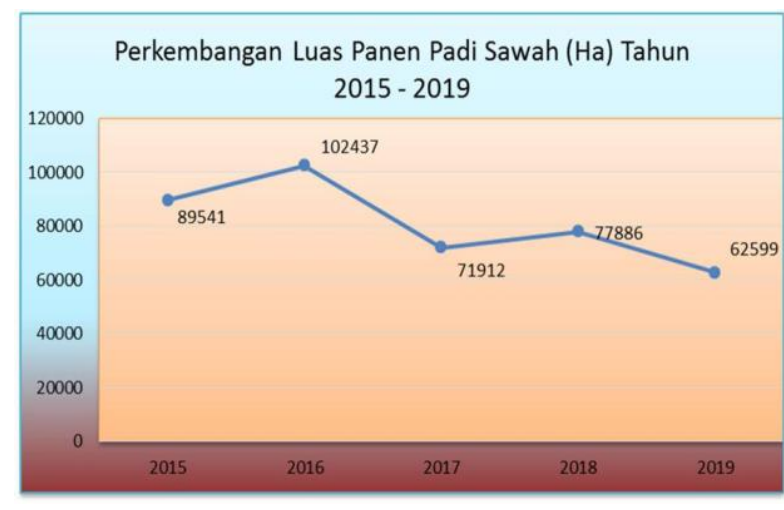

HASIL DAN PEMBAHASAN

\section{Pertanian Kabupaten Simalungun Sumatera Utara}

Sektor pertanian masih menjadi sektor yang berperan penting bagi perekonomian masyarakat di Kabupaten Simalungun. Luas wilayah Kabupaten Simalungun sebesar $366.960 \mathrm{~km}^{2}$ terdiri dari lahan sawah 31.273 hektar, lahan pertanian bukan sawah sebesar 366.960 hektar dan lahan bukan pertanian sebesar 2.320 hektar. Sektor pertanian merupakan lokomotif pembangunan perekonomian Kabupaten Simalungun. Ini terlihat dari komposisi Pendapatan Domestik Regional Bruto (PDRB) pada tahun 2019, dimana lapangan usaha pertanian, kehutanan dan perikanan memberikan kontribusi sebesar 48,67 persen terhadap perekonomian Kabupaten Simalungun.

Lahan pertanian sawah di Kabupaten Simalungun memiliki luas sebesar 31.273 hektar. Potensi lahan dapat menjadi modal untuk pengembangan pertanian padi dan memberikan sumbangan bagi perekonomian Kabupaten Simalungun terutama pada pertanian tanaman pangan. Berdasarkan data yang diperoleh dari BPS Kabupaten Simalungun pada tahun 2019, Kabupaten Simalungun merupakan penghasil padi
Sumatera Utara. Lahan sawah di Kabupaten Simalungun terluas adalah lahan sawah irigasi dengan luas sebesar 31.093 hektar $(99,42 \%)$ dari total lahan sawah. Sedangkan lahan sawah non irigasi hanya sebesar 180 hektar $(0,57 \%)$ yang dapat dilihat pada gambar 1.

\section{Gambar 1. Perkembangan Luas Panen Padi Sawah di Kabupaten Simalungun Tahun 2015-2019 (hektar)}

Gambar 1 menunjukkan bahwa dari tahun 2015-2019 luas lahan padi sawah di Kabupaten Simalungun mengalami penurunam di tahun 2019. Siklus tanam padi sawah tahun 2019 hanya dilakukan dalam satu kali tanam pada sawah irigasi dan non irigasi. Selain itu, frekuensi tanam padi dengan menggunakan lahan sawah irigasi mengalami penurunan sebesar 1,07 persen jika dibandingkan dengan tanam sebelumnya yaitu 30.224 hektar, sedangkan untuk padi sawah non irigasi tidak mengalami penurunan frekuensi tanam. Perkembangan luas panen padi sawah Kabupaten Simalungun pada tahun 20152019 (Gambar 1), tahun 2016 merupakan puncak tertinggi penanaman padi dengan luas sebesar 102.437,5 hektar dan paling rendah pada tahun 2015 sebesar 89.541 hektar luas tanam.

Luas panen padi sawah di Kabupaten Simalungun jika dilihat berdasarkan perkembangannya, maka dari tahun 20152019 (Gambar 2) puncak tertinggi luas tanam terjadi pada tahun 2019 sebesar 90.054 hektar dan terendah di tahun 2016 sebesar 10.221,5 hektar. Ini terjadi dikarenakan tahun 2016 pemerintah Kabupaten Simalungun melakukan suatu program bernama UPSUS. Program tersebut bertujuan untuk meningkatkan produksi tanam padi. Perkembangan luas tanam padi 
ladang di Kabupaten Simalungun dapat dilihat pada gambar 2 .

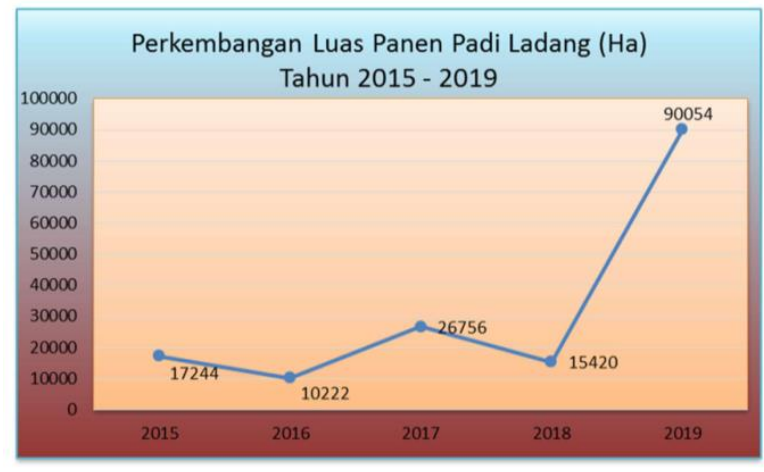

Gambar 2. Perkembangan Luas Panen Ladang Padi di Kabupaten Simalungun Tahun 2015-2019 (hektar)

Selain itu, di Kabupaten Simalungun juga terdapat tanaman holtikultura. Beberapa Sentra tanaman holtikultura yang ada di Kabupaten Simalungun berada di Kecamatan Pematang Bandar, Raya, Panombeian Panei, Purba dan Silimakuta.
Sedangkan untuk sentra produksi bawang merah di kabupaten ini terutama di daerah pinggiran Danau Toba.

\section{Perkembangan Distribusi Sektor Pertanian Kabupaten Simalungun}

Distribusi adalah penyaluran barang maupun jasa yang di produksi oleh produsen untuk sampai pada konsumen. Menurut (Yasrizal dan Hasan, 2017) sektor pertanian semakin mengalami pertumbuhan kearah yang positif dan mampu memberikan kontribusi terhadap penyerapan tenaga kerja. Hal ini juga berdampak pada peningkatan pembangunan terutama bagi sektor pertanian. Adapun perkembangan distribusi sektor pertanian di Kabupaten Simalung dapat di lihat pada tabel 2.

Tabel 2. Distribusi Persentase Produk Domestik Regional Bruto Kabupaten Simalungun Atas Dasar Harga Berlaku Menurut Lapangan Usaha (Juta Rp) pada Tahun 2015-2019

\begin{tabular}{lccccc}
\hline \multirow{2}{*}{ LAPANGAN USAHA } & \multicolumn{5}{c}{ TAHUN } \\
\cline { 2 - 6 } & $\mathbf{2 0 1 5}$ & $\mathbf{2 0 1 6}$ & $\mathbf{2 0 1 7}$ & $\mathbf{2 0 1 8}$ & $\mathbf{2 0 1 9}$ \\
\hline Pertanian, Kehutanan, dan Perikanan & 51,70 & 50,89 & 49,49 & 48,69 & 48,67 \\
Pertambangan dan Penggalian & 0,25 & 0,24 & 0,24 & 0,24 & 0,23 \\
Industri Pengolahan & 11,93 & 11,96 & 12,37 & 12,40 & 12,00 \\
Pengadaan Listrik, Gas & 0,07 & 0,06 & 0,07 & 0,07 & 0,07 \\
Konstruksi & 9,51 & 9,85 & 10,24 & 10,55 & 10,61 \\
Perdagangan Besar-Eceran, dan Reparasi Mobil dan & 14,89 & 15,31 & 15,94 & 16,42 & 16,79 \\
Sepeda Motor & 1,65 & 1,70 & 1,68 & 1,68 & 1,71 \\
Transportasi dan Pergudangan & 0,96 & 0,95 & 0,95 & 0,94 & 0,93 \\
Penyediaan Akomodasi dan Makan Minum & 0,58 & 0,56 & 0,57 & 0,55 & 0,54 \\
Informasi dan Komunikasi & 1,16 & 1,18 & 1,15 & 1,12 & 1,11 \\
Jasa Keuangan & 0,92 & 0,92 & 0,92 & 0,91 & 0,94 \\
Real Estate & 0,09 & 0,09 & 0,09 & 0,09 & 0,09 \\
Jasa Perusahaan & 1,05 & 1,05 & 1,05 & 1,06 & 1,08 \\
Jasa Pendidikaan & 0,37 & 0,38 & 0,38 & 0,39 & 0,41 \\
Jasa Kesehatan dan Kegiatan Sosial/human & & $T a b$ & 2, &
\end{tabular}

Sumber : BPS Kabupaten Simalungun, 2020

Tabel 2, data distribusi persentase

PDRB Kabupaten Simalungun pada lapangan usaha pertanian, kehutanan dan perikanan, dapat dilihat bahwa sektor 
pertanian adalah lokomotif dalam pembangunan ekonomi bagi Kabupaten Simalungun. Hal ini dapat dilihat dari pendapatan yang berasal dari PDRB Kabupaten Simalungun untuk sektor pertanian, kehutanan dan perikanan pada tahun 2019 memberikan kontribusi sebesar 48,67 persen, yang kemudian di ikuti oleh sektor perdagangan besar-eceran, dan reparasi mobil dan sepeda motor di tahun 2019 sebesar 16,79 persen. Menurut (Abraham dan Kota, 2016) bahwa untuk meningkatkan perekonomian, upaya yang dapat dilakukan yaitu dengan mengembangkan sektor pertanian sebagai leading sector. (Permatasari, Priyarsono dan Rifin, 2017) bahwa meningkatnya pendapatan PDRB yang berasal dari sektor pertanian, akan memberikan kontribusi yang akan mempengaruhi tingkat kesejahteraan masyarakat.

\section{PDRB Per-Kapita Kabupaten Simalungun}

Kesejahteraan masyarakat dapat diketahui melalui perkembangan Produk Domestik Regional Bruto (PDRB). Data perkembangan PDRB Kabupaten Simalungun dapat dilihat pada tabel 3.

Tabel 3. Distribusi Produk Domestik Regional Bruto Kabupaten Simalungun Atas Dasar Harga Berlaku Menurut Lapangan Usaha Tahun 2015-2019

\begin{tabular}{|c|c|c|c|c|c|}
\hline \multirow{2}{*}{ LAPANGAN USAHA } & \multicolumn{5}{|c|}{ TAHUN } \\
\hline & 2015 & 2016 & 2017 & 2018 & 2019 \\
\hline $\begin{array}{lll}\text { Pertanian, } & \text { Kehutanan, } & \text { dan } \\
\text { Perikanan } & & \end{array}$ & 14034981,7 & 15328444.4 & 16249888.5 & 17259182.5 & 18523060.9 \\
\hline Pertambangan dan Penggalian & 66884.5 & 73632.4 & 78283.9 & 83662.6 & 88261.4 \\
\hline Industri Pengolahan & 3238590.5 & 3601648.2 & 4061236.7 & 4396181.3 & 4565797.5 \\
\hline Pengadaan Listrik, Gas & 18435.2 & 19386.1 & 21874.8 & 23699.3 & 26040.4 \\
\hline $\begin{array}{l}\text { Pengadaan Air, Pengelolaan } \\
\text { Sampah, Limbah dan Daur Ulang }\end{array}$ & 23553.8 & 25929.2 & 28920.2 & 31228.4 & 32564.5 \\
\hline Konstruksi & 2582263.8 & 2967810.2 & 3362823.8 & 3739919.6 & 4037563.2 \\
\hline $\begin{array}{l}\text { Perdagangan Besar dan Eceran, dan } \\
\text { Reparasi Mobil dan Sepeda Motor }\end{array}$ & 4042409.9 & $4610,789.7$ & 5234497.7 & 5820480.5 & 6389218.5 \\
\hline Transportasi dan Pergudangan & 446731.5 & 511178.1 & 551234.1 & 596287.6 & 651467.3 \\
\hline $\begin{array}{l}\text { Penyediaan Akomodasi dan Makan } \\
\text { Minum }\end{array}$ & 261739.4 & 286294.1 & 310593.1 & 332375.7 & 355380.2 \\
\hline Informasi dan Komunikasi & 156228.7 & 169729.8 & 185915.2 & 195215.8 & 204436.2 \\
\hline Jasa Keuangan & 313943.6 & 356864.2 & 376588.9 & 398363.7 & 422878.0 \\
\hline Real Estate & 250598.0 & 276195.6 & 302694.4 & 323763.8 & 357102.5 \\
\hline Jasa Perusahaa & 24353.6 & 26827.1 & 29853.0 & 32112.5 & 35562.5 \\
\hline Jasa Pendidikaan & 286077.6 & 316098.8 & 345449.0 & 375978.5 & 412334.8 \\
\hline $\begin{array}{l}\text { Jasa Kesehatan dan Kegiatan } \\
\text { Sosial/human }\end{array}$ & 100880.3 & 114399.9 & 124855.3 & 138809.1 & 154143.5 \\
\hline Jumlah & 25847672.1 & 28685227.8 & 31264708.6 & 33747260.9 & 36255811.4 \\
\hline
\end{tabular}

Sumber : BPS Kabupaten Simalungun, 2020

Tabel 3, data PDRB pada Kabupaten Simalungun jika dilihat pada tahun 2019 diketahui PDRB sebesar 38,06 triliun rupiah. Berdasarkan data dari tahun 2015- 
2019 mengalami peningkatan. Sektor pertanian, kehutanan dan perikanan memberikan kontribusi PDRB yang cukup besar. Menurut (Permatasari, Priyarsono dan Rifin, 2017) bahwa kontribusi yang diberikan oleh sektor pertanian akan mengoptimalkan pada peranan pembangunan pertanian dengan pemanfaatan sumber daya manusia dalam menggerakan roda perekonomian wilayah.

\section{Laju Pertumbuhan PDRB Kabupaten Simalungun}

Tingkat perkembangan kegiatan ekonomi suatu wilayah dapat diukut dengan laju pertumbuhan Produk Domestrik Regional Bruto (PDRB). Semakin meningkat dan menunjukkan angka positif, maka perekonomian wilayah tersebut dikatakan baik. (Romhadhoni, Faizah dan Afifah, 2019), pertumbuhan ekonomi yang semakin tinggi pada suatu wilayah, maka perekonomian wilayah tersebut semakin baik. Pertumbuhan ekonomi wilayah salah satunya dapat dilihat dari laju pertumbuhan. Dengan semakin baiknya laju pertumbuhan PDRB maka produksi dan jasa yang dihasilkan akan mengalami peningkatan dan mampu menyerap tenaga kerja lebih banyak sehingga akan mengurangi angka pengangguran dan juga angka kemiskinan masyarakat. Laju pertumbuhan PDRB Kabupaten Simalungun dapat dilihat pada tabel 4.

Tabel 4. Laju Pertumbuhan Produk Domestik Regional Bruto Kabupaten Simalungun Atas Dasar Harga Berlaku Menurut Lapangan Usaha (Persen) 2017-2019

\begin{tabular}{|c|c|c|c|c|c|}
\hline \multirow{2}{*}{ LAPANGAN USAHA } & \multicolumn{5}{|c|}{ TAHUN } \\
\hline & 2015 & 2016 & 2017 & 2018 & 2019 \\
\hline Pertanian, Kehutanan, dan Perikanan & 2,00 & 9,22 & 6,01 & 6,21 & 7,32 \\
\hline Pertambangan dan Penggalian & 12,67 & 10,09 & 6,32 & 6,87 & 5,50 \\
\hline Industri Pengolahan & 9,76 & 11,21 & 12,76 & 8,25 & 3,86 \\
\hline Pengadaan Listrik, Gas & 6,11 & 5,16 & 12,84 & 8,34 & 9,88 \\
\hline $\begin{array}{l}\text { Pengadaan Air, Pengelolaan Sampah, Limbah } \\
\text { dan Daur Ulang }\end{array}$ & 13,89 & 10,09 & 11,53 & 7,98 & 4,28 \\
\hline Konstruksi & 15,42 & 14,93 & 13,31 & 11,21 & 7,96 \\
\hline $\begin{array}{l}\text { Perdagangan Besar dan Eceran, dan Reparasi } \\
\text { Mobil dan Sepeda Motor }\end{array}$ & 14,80 & 14,06 & 13,53 & 11,19 & 9,77 \\
\hline Transportasi dan Pergudangan & 14,58 & 14,43 & 7,84 & 8,17 & 9,25 \\
\hline Penyediaan Akomodasi dan Makan Minum & 10,08 & 9,38 & 8,49 & 7,01 & 6,92 \\
\hline Informasi dan Komunikasi & 6,42 & 8,64 & 9,54 & 5,00 & 4,72 \\
\hline Jasa Keuangan & 22,58 & 13,67 & 5,53 & 5,78 & 6,15 \\
\hline Real Estate & 12,15 & 10,21 & 9,59 & 6,96 & 10,30 \\
\hline Jasa Perusahaan & 10,16 & 10,16 & 11,28 & 7,57 & 10,74 \\
\hline Jasa Pendidikaan & 9,44 & 10,49 & 9,29 & 8,84 & 9,67 \\
\hline Jasa Kesehatan dan Kegiatan Sosial/human & 9,33 & 13,40 & 9,14 & 11,18 & 11,05 \\
\hline
\end{tabular}

Sumber : BPS Kabupaten Simalungun, 2020

Tabel 4, pada tahun 2019 laju pertumbuhan PDRB pada Kabupaten Simalungun sebesar 5,20 persen, pada tahun 2018 sebesar 5,18. Sehingga dapat disimpulkan bahwa laju pertumbuhan PDRB semakin mengalami peningkatan tiap tahunnya dan memberikan kontribusi terhadap pertumbuhan perekonomian Kabupaten Simalungun. 
Peranan Sektor Pertanian Kabupaten Simalungun

Pertanian merupakan salah satu sektor yang menjadi penggerak utama kegiatan ekonomi Kabupaten Simalungun salah satunya kegiatan pembangunan wilayah. Hal ini tergambar dalam Produk
Domestik Regional Bruto (PDRB) Kabupaten Simalungun yang menunjukkan bahwa nilai PDRB Sektor Pertanian, kehutanan dan perikanan mengalami peningkatan mulai dari tahun 2015-2019. Hal tersebut dapat dilihat dalam tabel pada tabel 5 berikut ini.

Tabel 5. Sektor Basis berdasarkan LQ PDRB Menurut Lapangan Usaha Kabupaten Simalungun Tahun 2015-2019

\begin{tabular}{|c|c|c|c|c|c|c|}
\hline \multirow{2}{*}{ LAPANGAN USAHA } & \multicolumn{5}{|c|}{ TAHUN } & \multirow[t]{2}{*}{ LQ } \\
\hline & 2015 & 2016 & 2017 & 2018 & 2019 & \\
\hline Pertanian, Kehutanan, dan Perikanan & 3,65 & 3,58 & 3,55 & 2,79 & 3,60 & 3,44 \\
\hline Pertambangan dan Penggalian & 0,03 & 0,03 & 0,03 & 0,08 & 0,03 & 0,04 \\
\hline Industri Pengolahan & 0,54 & 0,55 & 0,58 & 1,79 & 0,57 & 0,81 \\
\hline Pengadaan Listrik, Gas & 0,06 & 0,05 & 0,05 & 0,04 & 0,06 & 0,05 \\
\hline $\begin{array}{l}\text { Pengadaan Air, Pengelolaan Sampah, Limbah dan } \\
\text { Daur Ulang }\end{array}$ & 1,12 & 1,14 & 1,20 & 0,96 & 1,19 & 1,12 \\
\hline Konstruksi & 0,89 & 0,90 & 0,93 & 0,74 & 0,93 & 0,88 \\
\hline $\begin{array}{l}\text { Perdagangan Besar dan Eceran, dan Reparasi } \\
\text { Mobil dan Sepeda Motor }\end{array}$ & 1,07 & 1,10 & 1,16 & 0,93 & 1,21 & 1,09 \\
\hline Transportasi dan Pergudangan & 0,31 & 0,31 & 0,29 & 0,23 & 0,29 & 0,29 \\
\hline Akomodasi dan Makan Minum & 0,31 & 0,31 & 0,31 & 0,25 & 0,32 & 0,30 \\
\hline n Komunikasi & 0,16 & 0,15 & 0,14 & 0,11 & 0,13 & 0,14 \\
\hline Jasa $\mathrm{H}$ & 0,27 & 0,27 & 0,26 & 0,20 & 0,25 & 0,25 \\
\hline Real 1 & 0,31 & 0,31 & 0,31 & 0,25 & 0,32 & 0,30 \\
\hline Jasa Perusahaan & 0,05 & 0,05 & 0,05 & 0,04 & 0,05 & 0,05 \\
\hline Jasa & 0,30 & 0,30 & 0,30 & 0,24 & 0,31 & 0,29 \\
\hline Jasa Kesehatan dan Kegiatan Sosial/human & 0,33 & 0,34 & 0,34 & 0,27 & 0,35 & 0,32 \\
\hline
\end{tabular}

Sumber : BPS Kabupaten Simalungun, 2020 (diolah)

Pada tabel 5 menunjukkan bahwa sektor basis berdasarkan nilai LQ dengan menggunakan data PDRB dari tahun 20152019 pada Kabupaten Simalungun, diperoleh hasil bahwa sektor basis tertinggi di Kabupaten Simalungun adalah sektor pertanian, kehutanan dan perikanan dengan nilai $\mathrm{LQ}=3,44$. Diikuti oleh pengadaan air, pengelolaan sampah, limbah dan daur ulang dengan nilai $\mathrm{LQ}=1,12$ dan perdagangan besar dan eceran, dan reparasi mobil dan sepeda motor dengan nilai $\mathrm{LQ}=1,09$.
Sektor pertanian mengalami pertumbuhan positif. Pada tiap tahunnya sektor pertanian, kehutanan dan perikanan, secara berturut-turut pada tahun 2015 nilai LQ sebesar 3,65, tahun 2016 sebesar 3,58, tahun 2017 sebesar 3,55, tahun 2018 sebesar 2,79 dan tahun 2019 sebesar 3,60. Selama tahun 2015-2019, sektor pertanian memberikan kontribusi terhadap pembangunan PDRB di Kabupaten Simalungun. 
Komoditas unggulan pertanian di Kabupaten Simalungun yaitu tanaman sayuran. Potensi tanaman sayuran di Kabupaten Simalungun pada tahun 2019 meliputi bawang merah, cabai besar, cabai rawit, kubis, wortel, kentang, terung, tomat, petsai/sawi, buncis, kacang panjang, ketimun, kangkung, kacang merah, bayam, petsai (Gambar 3).

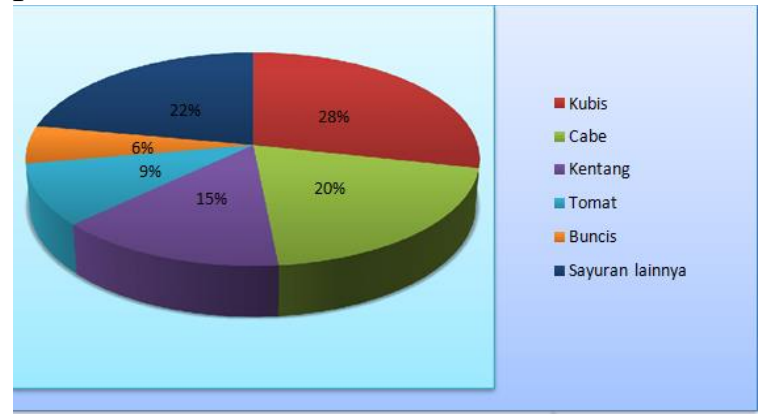

Gambar 3. Luas Panen Sayuran Tahun 2019 di Kabupaten Simalungun

Gambar 3 menunjukkan bahwa tanaman holtikultura sayur-sayuran yang memiliki potensi untuk dapat dikembangkan di Kabupaten Simalungun. Luas panen tanaman sayur-sayuran di Kabupaten Simalungun mencapai 11.190 hektar. Sedangkan sayuran utama yang menjadi primadona adalah kubis dengan luas panen mencapai 2.406 hektar $(21,50 \%)$, cabe besar dan cabe rawit sebesar 3.242 hektar (28,97\%), kentang sebesar 1.740 hektar $(15,55 \%)$, tomat sebesar 729 hektar $(6,51 \%)$, buncis sebesar 172 hektar (1,54\%).

Selain itu, jika dilihat dari produksi holtikultura tanaman sayur-sayuran yang ada di Kabupaten Simalungun produksi terbesar adalah komoditas kubis dengan total produksi yang dihasilkan sebesar 51.298 ton $(27,89 \%)$ yang dapat dilihat pada Gambar 4.

Gambar 4. Produksi Sayuran Tahun 2019 di Kabupaten Simalungun

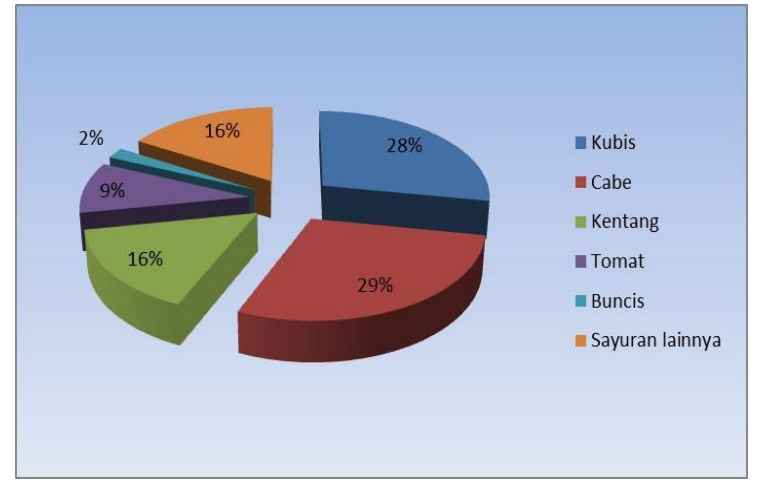

Pada gambar 4, total produksi tanaman holtikultura sayuran di Kabupaten Simalungun pada tahun 2019 sebesar 183.947 ton. cabai terdiri dari cabai besar dan cabai rawit dengan produksi sebesar 52.512 ton atau 28,55\%, kentang produksinya sebesar 28.691 ton atau $15,60 \%$, tomat sayur produksinya sebesar 17.531 ton atau $9,53 \%$, buncis dengan hasil produksi sebesar 3.756 ton atau 2,04\%, sedangkan untuk sayuran yang lain (petsai, bawang merah, kacang panjang, ketimun,terung dan lain-lain) produksinya sebesar 30.159 ton atau 16,39\%.

Komoditas jagung di Kabupaten Simalungun pada tahun 2019 memiliki luas sebesar 41.676,8 hektar dan produksi jagung mencapai 56,31 ton. Selain itu, produksi kacang tanah pada tahun 2019 sebesar 685,5 hektar dan produksi 12,25 ton. Selanjutnya kedelai pada tahun 2019 luas panen sebesar 1.004,5 hektar dan produksi 18,01 ton. Komoditas ubi kayu memiliki luas panen pada tahun 2019 sebesar 6.414,9 hektar dan produksi 332,43 ton dan komoditas ubi jalar dengan luas panen pada tahun 2019 seebsar 1.200,9 hektar. 
Disamping itu, pada sektor perkebunan di Kabupaten Simalungun adalah perkebunan rakyat (Gambar 5).

Gambar 5. Produksi Perkebunan Rakyat 2019 di Kabupaten Simalungun

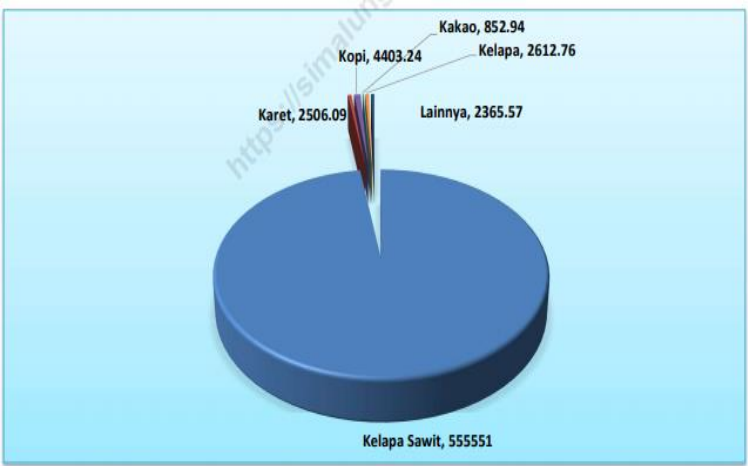

Pada tahun 2019, jenis tanaman perkebunan yang berpotensi untuk dikembangkan di Kabupaten Simalungun adalah kelapa sawit, karet, kopi, kakao dan kelapa. Pada tahun 2019, produksi tanaman perkebunan di Kabupaten Simalungun mencapai 568.291,6 ton. Kelapa sawit merupakan komoditas perkebunan dengan produksi tertinggi mencapai 555.551 ton $(97,76 \%)$ dengan total luas area tanam sebesar 35.958,59 hektar. Diikuti tanaman karet dengan produksi sebesar 2.506,09 ton $(0,44 \%)$, kopi robusta dan arabika sebesar $4.403,24$ ton $(0,77 \%)$, kakao produksi sebesar 852,94 ton $(0,15 \%)$, kelapa produksi sebesar 2.612,76 ton $(0,46 \%)$. Sektor perkebunan memiliki kontribusi terhadap penerimaan daerah jika mampu untuk meningkatkan produksi dan produktivitas bagi komoditas perkebunan tersebut (Januar, 2012).

\section{KESIMPULAN}

Nilai Produk Domestik Regional Bruto (PDRB) dapat dilihat dari pertumbuhan ekonomi pada wilayah tersebut. Jika dilihat dari PDRB Kabupaten
Simalungun pada sektor pertanian, kehutanan dan perikanan memiliki potensi untuk dikembangkan. Kontribusi PDRB sektor perikanan sebesar 48,67 persen dengan laju pertumbuhan sebesar 7,32. Berdasarkan hasil analisis LQ pada sektor pertanian di Kabupaten Simalungun merupakan sektor basis atau unggul dengan sumbangan sebesar 3,44 diikuti oleh Pengadaan Air, Pengelolaan Sampah, Limbah dan Daur Ulang sebesar 1,12 dan Perdagangan Besar dan Eceran, dan Reparasi Mobil dan Sepeda Motor sebesar 1,09. Adapun komoditas sektor pertanian holtikultura tanaman dan sayuran yang memberikan kontribusi yaitu kubis dengan luas panen mencapai 2.406 hektar $(21,50 \%)$. Dari tanaman pangan yaitu padi sawah dan Kelapa sawit merupakan komoditas perkebunan dengan produksi tertinggi mencapai 555.551 ton $(97,76 \%)$.

\section{DAFTAR PUSTAKA}

Abraham Pranata Silalahi, P. And Permata Wijayanti Jurusan Perencanaan Wilayah Dan Kota, W. (2016) 'Potensi Kerjasama Regional Usaha Mikro Kecil Menengah (Umkm) Berbasis Komoditas Pertanian Di Kabupaten Simalungun', Jurnal Tata Kota Dan Daerah.

Fadlina, I. M., Supriyono, B. And Soeaidy, S. (2013) 'Perencanaan Pembangunan Pertanian Berkelanjutan (Kajian Tentang Pengembangan Pertanian Organik Di Kota Batu) Sustainable Development Of Agrocultural (Studies On Organic Agricultural Development In Batu City )', J-Pal.

Hayati, M., Elfiana And Martina (2017) 'Peranan Sektor Pertanian Dalam Pembangunan Wilayah Kabupaten Bireuen Provinsi Aceh', Jurnal S. 
Pertanian.

Doi:

10.1017/Cbo9781107415324.004.

Januar, H. Dan J. (2012) 'Terhadap Pembangunan Wilayah Kabupaten Malinau [ Role And Plantation Development Strategy Toward Regional Establishment Of Malinau Regency ] Agritrop Jurnal Ilmu-Ilmu Pertanian 232 Agritrop Jurnal IlmuIlmu Pertanian', Agritrop Jurnal IlmuIlmu Pertanian.

Juhanis (2012) 'Pengaruh Sektor Unggulan Terhadap Pertumbuhan Ekonomi Wilayah Kabupaten Halmahera Selatan', Jurnal Plano Madani.

Bone, P. Et Al. (2016) 'Penentuan Komoditas Unggulan Sektor Pertanian Tanaman Pangan Di Kabupaten Bone, Sulawesi Selatan', Temu Ilmiah Iplbi .

Oktavia, H., Hanani, N. And Suhartini, S. (2016) 'Peran Sektor Pertanian Dalam Pembangunan Ekonomi Di Provinsi Jawa Timur (Pendekatan InputOutput)', Habitat. Doi: 10.21776/Ub.Habitat.2016.027.2.9.

Permatasari, N., Priyarsono, D. S. And Rifin, A. (2017) 'Perencanaan Pembangunan Ekonomi Wilayah Berbasis Pertanian Dalam Rangka Pengurangan Kemiskinan Di Kalimantan Barat', Jurnal Agribisnis Indonesia. Doi: 10.29244/Jai.2016.4.1.27-42.

Putra, S., Purwanto And Kismartini (2013) 'Perencanaan Pertanian Berkelanjutan Di Kecamatan Selo', Prosiding
Seminar Nasional Pengelolaan Sumberdaya Alam Dan Lingkungan 2013.

Romhadhoni, P., Faizah, D. Z. And Afifah, N. (2019) 'Pengaruh Produk Domestik Regional Bruto (Pdrb) Daerah Terhadap Pertumbuhan Ekonomi Dan Tingkat Pengangguran Terbuka Di Provinsi Dki Jakarta', Jurnal Matematika Integratif. Doi: 10.24198/Jmi.V14.N2.19262.115-121.

Sugiyono (2014) 'Metode Penelitian Pendidikan Pendekatan Kuantitatif, Kualitatif Dan R\&D.', In Metode Penelitian Ilmiah.

Sulistiawan, A., Ispriyarso, B. And Ristyawati, A. (2019) 'Bentuk Dan Mekanisme Perencanaan Keuangan Daerah Yang Partisipatif Guna Mewujudkan Akuntabilitas Publik', Jurnal Pembangunan Hukum Indonesia. Doi: 10.14710/Jphi.V1i2.146-157.

Syam, A. And Dermoredjo, S. (2001) 'Kontribusi Sektor Pertanian Dalam Pertumbuhan Dan Stabilitas Produk Domestik Bruto', Soca: Socioeconomics Of Agriculture And Agribusiness.

Yasrizal, . And Hasan, I. (2017) 'Pengaruh Pembangunan Sektor Pertanian Terhadap Distribusi Pendapatan Dan Kesempatan Kerja Di Indonesia', Jurnal Ilmu Ekonomi Dan Pembangunan. Doi: 10.20961/Jiep.V16i1.2320. 